\title{
THE PERSUASIVE COMMUNICATION TRAINING FOR REPRODUCTIVE HEALTH NECESSITY ON SEXUAL WORKER
}

\author{
Daesy Ekayanthi ${ }^{1 *}$, Fit Yanuar ${ }^{1}$ \\ ${ }^{1}$ Faculty of Communication, University of Sahid Jakarta \\ *ecieka.dof@gmail.com
}

\begin{abstract}
Reproductive Health is about all that is connected to the organ and the function and also the reproductive process of human body, which is objected to keep, prevent, and also give back the reproductive from its interference or anything unwanted. Sexual worker (the whore) are the susceptible communities for the sexual infected disease like HIV/AIDS. The increasing number of HIV/AIDS sufferers provide us the picture about the needs to enhance the awareness of reproductive health on sexual worker. It necessarily needs a persuasive communication techniques for the sake of the sexual workers itself, their family, as also their consumers, and more: the society. The persuasive communication techniques been taught cognitively to open the sexual worker's mind or to refresh them. The persuasive communication techniques been taught for the group and individual objective.
\end{abstract}

Keywords: persuasive communication, reproductive health, sexual worker.

\section{INTRODUCTION}

HIV/AIDS is still an important phenomenon especially in Indonesia. HIV/AIDS case give the impact economically and socially. A curement for the rest of someone's life would be a must for HIV/AIDS patients. It give impact economically for the patientsas also for the government that should spend some cost in a variety ways of help. Access of health service is another thing to be watchedattentively since not every health institution able and willing to receive HIV/AIDS patients. Moreover, HIV/AIDS sufferes are not welcome in the society.They are stigmatized as sick person, physically and morally. The stigma furthermore decrease the self confidence of the sufferes, they are afraid to socialize normally, and they live undercover, but it would not good for the preventing of HIV/AIDS in the society. They spread the desease undercoverly too. This is reinforced from the results of data on semiotics about condoms (journal semiotics of Bunda Mulia, 2015), the results obtained about their knowledge of HIV and AIDS are among others: dangerous diseases, infectious diseases, infectious disease has no cure, HIV and AIDS are the same disease the HIV virus said many died, AIDS was dirt.GOR Boker Ciracas in Jakarta Timur, is a location for prostitution activity. It is one of many places which HIV/AIDS is easily spread. The authors found about 200 sexual worker (the whore) prostitute themselves here every night. And, they do the business in a not safety condition. They do not use condom in their sexual transaction. It is such a harm for the sake of preventing HIV/AIDS spreading.

There are many reasons why they do not use condom in their sexual transaction, ne of them is consumer's demand. The consumer refuse to use it. The condom is not comfortable. It appears to be a dilemma situation for the sexual worker. If the sexual worker commit to use the condom, they will loose the customer. Not only now, but also in the future. It is a very big problem. The sexual worker decide to do their job almost all about the financial problem. They need money to feed their life, their family. But, from the field, the authors found that the sexual workers aware about the necessity of condom in their sexual activity. They know exactly that they can be infected HIV/AIDS if the transaction done without condom.

There is a need for the sexual worker to be able to conquer their consumer to use condom in sexual transaction. Through training sexual worker understand about the technique of persuasive communication. It is a technique to persuade the consumer to goal the transaction successfully but with the using of the condom in their sexual activity.Craig (in Little, 2008: 9) says that communication is the main process in which human life is lived, communication underlies reality.Based on the condition, the authors tried to give such an awareness to the sexual worker to give some time from themselves to learn 
some or more about persuasive communication approach and also would give some benefits for themselves, their family, the customers, as also for the society. This effort is to prevent the spread of HIV / AIDS.The team did it in GOR Boker, Ciracas, JakartaTimur.We taught 15 of all of sexual worker as the representaive from all of them. We also delivered some topics of motivation, self confidence, andshare our experience in persuasive communication.

\title{
METHOD
}

Time and Location:

June 2016 - Februari 2017. Location: Boker, Ciracas, Jakarta Timur.

\section{Tool andMaterial:}

A paper about persuasive communication is needed, as also some relevant pictures about persuasive communication which is also added by information of reproductive, meta plan flip chart.

\section{Method:}

Methods in this training are: counseling, discussion, practice.

Some approaches to the audience are: 1) To Understand the Communicator, 2) To Understand the Message and Persuasive Communication, 3) To Understand Message Receiver (Audience of Communicator).

\section{RESULT ANDDISCUSSION}

\begin{abstract}
About the communicator
To understanding the persuasive communication we can not let out ourselves from the involvement of sensitivity about the message to delivered. Mc. Guire (2003:64) figure out that in persuasive process there are two advanced steps beside the sensitivity,consist of retentionor content deposition which has been approved, andactionthat is suitable with the content.

Blake and Haroldsen(2014:9) said that all communication in its scale is intrapersonal communication, where the meaning inside the communication is always be the object of interpretation of human being. To understand ourselves as a communicator or message deliverer is an important thing. The communicator in implementating the using of condom in sexual transaction is the sexual worker itself. Based on the data that we (the author) have, we should confirm that only the succesful sexual worker have a good result in implementating the using of condom in sexual transaction. Only them, the successful person. The analysys is: they are needed by the customer, so they are able to persuade the customer to use the condom.

How about them that are not the best-seller as sexual worker? The answer is: their position is not good. The customer force them to do sexual activity without condom.In these case, after doing the counseling and discussion, we found that persuasive communications itself is not the answer for the sexual worker as a communicator in implementating the using of condom. They need more than that. They need some attractiveness in theirselves to make them attract the customers which then they are able persuade the customer to use the condom. For us, it is not our area. It is an area for the psychology science.

But, we've got help. Not from the psychology scientist. It was from the sexual worker community itself. The successful sexual worker was willing to help their colleagues to share their success. So, they gave the mentoring to guide the others how to be success in the business.

Based on the furthermore data, after implementating 'the recipe' we receive the newest data that some of them has got the better result. Eventhough it was not many, but the progress is positive.
\end{abstract}

\section{About the message and persuasive communication}

Message in a communication process in an important matter. Message should be produced in a balancing situation from the communicator to the receiver. That is why, persuasive communication is one of the solution. In persuasive communication, the message is delivered persuasively. Persuasive 
means no intimidation, no coercion. What we could find in persuasive matter is a nice and good technique in delivering the message.

Connected to the message in implementating the using of condom in sexual transaction between the sexual worker and their consumer, we taught the sexual worker to learn persuasive communication. We taught them how to smile, how to convince person, especially how to convince the consumer to use the condoms.

The consideration is healthiness and life.And the result is awesome. The sexual worker like the topic. And they practiced it in the field. But the real result has been informed above. Only the best-seller win. But however the improvement is releasing.

\section{About the receiver of communication (the message receiver)}

The team taught the sexual worker to know more about audience matter. Connected to the communciation process, they should deliver the message to make their audience understand them. Much failure in communication based on the failness to understand the receiver of the message. The receiver is the target of communication. The receiver in this matter is the consumer or customer of a sexual transaction. This consumer need to be changed, from the position of not using the condom to the position of using the condom.

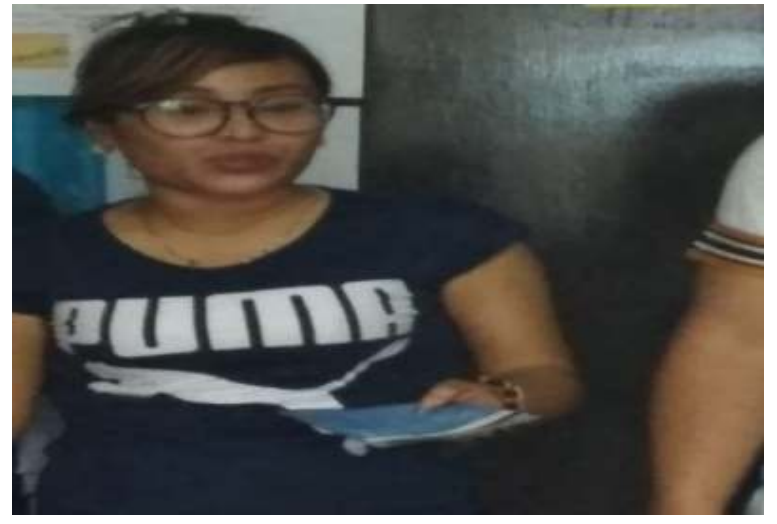

Figure 1. Practice of Communication Skills

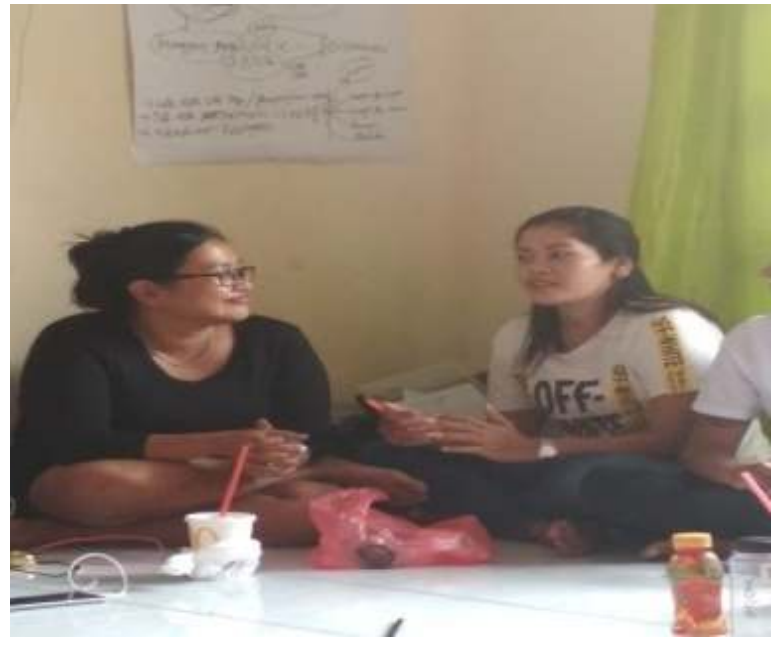

Figure2. A Group Discussion of Sexual Worker 


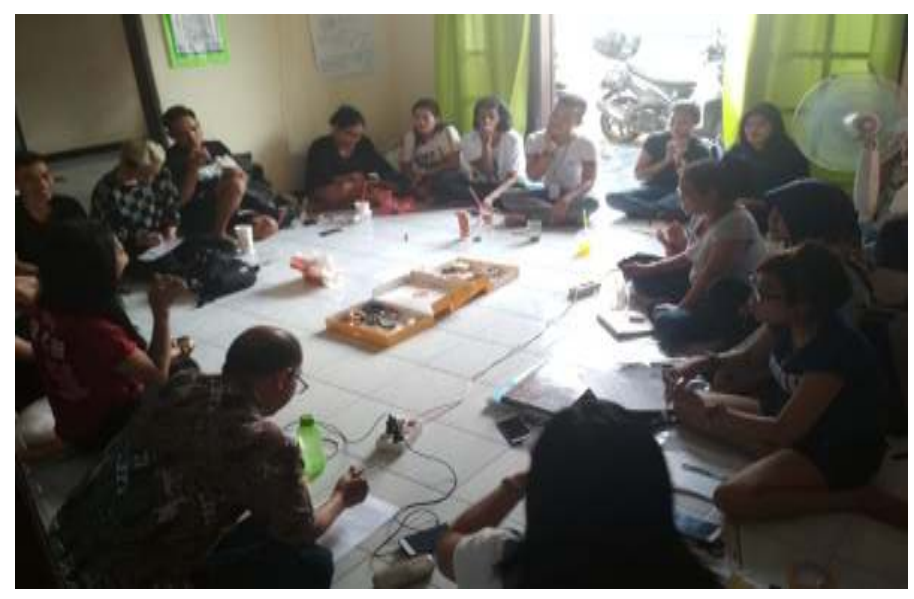

Figure 3. Counseling to the Sexual Worker

\section{The Implementating of Counseling}

There were three main components that needed to understand in such a persuasive communication approach, that is communicator (the deliver of the message), the message itself, and the receiver of communication).

From three times of counseling session, we could find some important words from the sexual worker, firstly what they say to the customers, i.e.:"I've got my test. It is good. Negative of the result. The using of condom prevent me from HIV/AIDS. I suggest you to do the test too, since you are familiar here as the customers." "I always tell my customers, that for such a long years I am free from HIV/AIDS. The using of condom is the secret."While, for the same persuasive communication that works for the sexual worker colleagues in order to miss the HIV/AIDS, they said:"We need a prime condition for this business. We should be healthy. We should take care for our body: take a very good care for our vagina, since it is our asset. Once we have a desease, what else it is HIV/AIDS, then all the money that we've been collected will be gone. Away from us, only for the curement, for the medicine."“For me, I would always remind them to get back three monthsa times. It is a must."

\section{CONCLUSION}

The skill of persuasive communication is a communication practice that should be learned from time to time related to the need of the receiver of a message communication as also the challange of the situation. To understand ourselves as a communicator, and to be aware about the righteous message model and approach for the receiver of the message, which in this case the customer and the sexual worker, would give a good communication objective result. Therefore, it would make an effort of the using of persuasive communication for the sexual worker to prevent the prevalance of HIV/AIDS, succeed.

\section{REFERENCES}

Ekayanthi, D. (2015). Journal of Semiotika, University of Bunda Mulia.(Vol. 9 No.1)http//:journal.ubm.ac.id/index.php/semiotika.

Littlejohn, S. W., \& Foss, K. A. (2010).Theories of human communication. Waveland press.

Nasrullah, R. (2012). Komunikasi Antar budaya di Era Budaya Siber. Jakarta, Kencana Prenada Media Group.

Syaifuddin, A. (1995). Sikap Manusia Teori dan Pengukurannya. 